\title{
GAMBARAN TINGKAT PENGETAHUAN IBU HAMIL TENTANG TANDA BAHAYA KEHAMILAN BERDASARKAN KARAKTERISTIK IBU DI DESA SENGON KEC. TANJUNG KABUPATEN BREBES
}

\author{
Siti Fatimah, Umi Solikhatun \\ STIKes Brebes \\ helga.abhinaya@gmail.com
}

\begin{abstract}
Abstrak
Angka kematian ibu di Indonesia masih tinggi yaitu 305 per 100.000, sedangkan angka kematian ibu di Desa Sengon Kecamatan Tanjung Kabupaten Brebes yaitu 1,25/1000 kelahiran hidup. Sekitar 162.000 wanita meninggal setiap tahunnya diakibatkan komplikasi kehamilan serta persalinan yang diantaranya disebabkan oleh terlambatnya mengetahui tanda bahaya pada kehamilan. Tujuan penelitian ini bertujuan untuk mengetahui pengetahuan ibu hamil tentang tanda bahaya kehamilan.

Desain penelitian ini adalah deskriptif yaitu suatu metode penelitian yang dilakukan dengan tujuan utama untuk membuat gambaran atau deskripsi tentang suatu keadaan secara objektif, dengan jumlah sampel sebanyak 34 orang. Berdasarkan penelitian ini diperoleh dari 34 responden rata-rata ibu hamil yang berumur antara 21-25 tahun yaitu 12 orang (35,3\%), mayoritas pendidikan tamat SMA yaitu 16 orang (47,1\%), mayoritas yang hamil multipara adalah 15 orang $(44,1 \%)$, ibu hamil mempunyai mayoritas pengetahuan baik yaitu 24 orang (70,6\%). Secara keseluruhan disimpulkan bahwa pengetahuan ibu hamil tentang tanda bahaya pada kehamilan di Desa Sengon Kec. Tanjung Kabupaten Brebes berpengetahuan baik, mayoritas ibu hamil berusia 21-25 tahun, mayoritas pendidikan yaitu tamatan SMA, dan mayoritas paritas yaitu multipara, harapan dari penelitian ini supaya instansi pelayanan kesehatan lebih memberikan penyuluhan kesehatan seawal mungkin kepada ibu hamil di Trimester Pertama mengenai tanda-tanda bahaya pada kehamilan.
\end{abstract}

Kata Kunci:Ibu hamil, tanda bahaya kehamilan

\section{Pendahuluan}

Menurut Varney (2007) setiap menit dan setiap hari di dunia, seorang ibu meninggal dunia akibat komplikasi yang 
JURNAL OF NURSING PRACTICE AND EDUCATION VOL. 01 NO. 02, JUNI 2021

DOI: $10.34305 /$ JNPE.V1I2.291

muncul selama masa hamil dan persalinan. Sebagian besar kematian ini tidak dapat dihindari. Indonesia sebagai negara berkembang masih memiliki angka kematian ibu yang sangat tinggi. Hasil Survei Kesehatan Rumah Tangga (SKRT) dan Survei Demografi dan Kesehatan Indonesia (SDKI) Tahun 2015, 305 per 100.000 kelahiran hidup (Statistik, 2015).

Kematian ibu di Indonesia dapat disebabkan oleh dua hal, yang pertama adalah penyebab kematian langsung yaitu kematian ibu karena komplikasi selama kehamilan, bersalin dan karena penanganan persalinan seperti sectio caesarea, abortus. Golongan kedua adalah penyebab kematian yang tidak langsung yaitu kematian ibu dapat diperberat karena kehamilan seperti anemia, diabetes mellitus, penyakit jantung, TBC (Depkes R I, 2014).

Kebijakan Departemen Kesehatan Republik Indonesia dalam upaya mempercepat penurunan Angka Kematian Ibu ditempuh melalui pendekatan pelayanan ibu dan anak di tingkat dasar dan rujukan yang pada dasarnya mengacu pada intervensi strategi "empat pilar safe motherhood" yaitu program $\mathrm{KB}$, pelayanan ANC, persalinan yang aman, cakupan pelayanan obstetri yang hendaknya dilaksanakan oleh seluruh lembaga
Ciptaan disebarluaskan di bawah Lisensi Creative Commons AtribusiNonKomersial-BerbagiSerupa 4.0

Internasional.

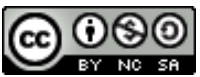

kesehatan RI, Puskesmas dan lembaga instansi swasta, dan juga diperlukan penekanan pada kejadian 4 terlalu yaitu terlalu muda, terlalu tua hamil dan melahirkan, terlalu dekat jarak antara kehamilan dan persalinan dan kehamilan yang dapat ditekan serendah mungkin, (Saifuddin, 2018, hal. 58).

Minimnya penyuluhan tentang tanda bahaya kehamilan yang dilakukan oleh pihak Puskesmas membuat banyak ibu hamil yang belum mengerti sepenuhnya tentang tanda bahaya kehamilan. Pengenalan tanda bahaya kehamilan sedini mungkin akan lebih baik untuk ibu hamil, mengenai tandatanda bahaya kehamilan dapat dipelajari oleh ibu hamil pada buku yang telah diberikan pihak Puskesmas ialah KMS ibu hamil. Pentingnya pada buku KMS adalah guna menambah wawasan ibu hamil mengenai kehamilan yang dialaminya.

Data dari studi pendahuluan tingkat pengetahuan ibu hamil tentang tanda bahaya kehamilan di Desa Sengon Kecamatan Tanjung, terhadap 5 responden, didapatkan 2 orang ibu hamil yang tingkat pengetahuannya baik dan 3 orang ibu hamil yang tingkat pengetahuannya kurang baik.

Berdasarkan uraian diatas penulis tertarik untuk melakukan penelitian "Tingkat Pengetahuan Ibu Hamil Tentang 
JURNAL OF NURSING PRACTICE AND EDUCATION VOL. 01 NO. 02, JUNI 2021

DOI: $10.34305 / J N P E . V 1 I 2.291$

Tanda Bahaya Kehamilan di Desa Sengon Kecamatan Tanjung Kabupaten Brebes.

\section{Metode}

Dalam penelitian ini penulis menggunakan jenis penelitian deskriptif. Menurut Notoatmodjo (2010: 138), penelitian deskriptif adalah suatu metode penelitian yang dilakukan dengan tujuan utama untuk membuat gambaran atau deskripsi tentang suatu keadaan secara objektif. Rancangan penelitian yang digunakan adalah metode cross sectional. Menurut Notoatmodjo (2012: 145), penelitian cross sectional adalah suatu penelitian untuk mempelajari dinamika korelasi antara faktor-faktor resiko dengan efek, dengan cara pendekatan, observasi atau mengumpulkan data sekaligus pada suatu saat.

Adapun rancangan penelitiannya
Ciptaan disebarluaskan di bawah Lisensi Creative Commons AtribusiNonKomersial-BerbagiSerupa 4.0 Internasional.

menggunakan rancangan Cross sectional. Menurut Notoatmodjo (2017: 22)penelitian cross sectional yaitu suatu metode yang bertujuan untuk mempelajari hubungan penyakit dengan paparan dengan cara mengamati status paparan dan penyakit secara serentak pada individu dari populasi tunggal pada suatu saat atau periode tertentu.

\section{Hasil Penelitian}

Dari hasil penelitian yang dilakukan di Desa Sengon Kecamatan Tanjung Kabupaten Brebes, diperoleh data 34 orang ibu hamil yang tingkat pengetahuan tentang Tanda Bahaya Kehamilan berdasarkan umur,paritas dan pendidikan.

Setelah dilakukan penelitian didapatkan hasil tentang umur ibu hamil yang tercantum pada tabel di bawah ini:

\section{Tabel 1 Distribusi Frekuensi Umur}

\begin{tabular}{cccc}
\hline No & Umur & Frekuensi & $\begin{array}{c}\text { Perse } \\
\text { ntase } \\
(\boldsymbol{\%})\end{array}$ \\
\hline 1 & $<20$ th & 5 & 14,7 \\
2 & $21-25$ th & 10 & 29,4 \\
3 & $26-30$ th & 8 & 23,5 \\
4 & $31-35$ th & 5 & 14,7 \\
5 & $>35$ th & 7 & 20,6 \\
\hline & Jumlah & 34 & 100 \\
\hline
\end{tabular}

Berdasarkan data distribusi tabel 1 didapatkan Persentase paling banyak adalah umur 21 - 25 tahun dengan jumlah 10 orang
$(26,6 \%)$ dan yang paling rendah adalah responden dengan umur $<20$ tahun dan 3135 tahun dengan jumlah 5 orang $(14,7 \%)$. 
Tabel 2 Distribusi Frekuensi Pendidikan

\begin{tabular}{cccc}
\hline No & Tingkat Pendidikan & $\begin{array}{c}\text { Frekuen } \\
\text { si }\end{array}$ & $\begin{array}{c}\text { Presenta } \\
\text { se }(\%)\end{array}$ \\
\hline 1 & Tidak tamat SD & 0 & 0 \\
2 & Tamat SD & 7 & 20,6 \\
3 & Tamat SMP & 8 & 23,5 \\
4 & Tamat SMA & 18 & 53 \\
5 & Tamat PT & 1 & 2,9 \\
\hline & Jumlah & 34 & 100 \\
\hline
\end{tabular}

rendah adalah tingkat pendidikan Perguruan

Berdasarkan data distribusi tabel 2 Tinggi dengan jumlah 1 orang (2,9\%).

bahwa jumlah responden terbesar adalah tingkat pendidikan Tamatan SMA dengan jumlah 18 orang $(53 \%)$ dan yang paling

Tabel 3 Distribusi Frekuensi Paritas

\begin{tabular}{clcc}
\hline No & Paritas & $\begin{array}{c}\text { Frekue } \\
\text { nsi }\end{array}$ & Persentase (\%) \\
\hline 1 & Primipara & 13 & 38,2 \\
2 & Multipara & 18 & 53 \\
3 & Grandemulti & 3 & 8,8 \\
\hline & Jumlah & 34 & 100 \\
\hline
\end{tabular}

yang paling rendah adalah grandemulti yaitu

Berdasarkan tabel di atas 3 orang $(8,8 \%)$.

menunjukan bahwa jumlah paritas terbanyak adalah Multipara yaitu 18 orang (53\%) dan

Tabel 4 Distribusi Frekuensi Berdasarkan Tingkat Pengetahuan Tentang Tanda Bahaya Kehamilan

\begin{tabular}{clccc}
\hline No & & Pengetahuan & Frekuensi & Persentase (\%) \\
\hline 1 & Baik & 24 & 70,6 \\
2 & Cukup & 6 & 17,6 \\
3 & Kurang & 4 & 11,8 \\
\hline & Jumlah & 34 & 100 \\
\hline
\end{tabular}
didapatkan persentase paling banyak adalah Dari data distribusi tabel 4 pengetahuan dengan kategori baik yaitu 24 
JURNAL OF NURSING PRACTICE AND EDUCATION VOL. 01 NO. 02, JUNI 2021

DOI: $10.34305 / J N P E . V 1 I 2.291$

orang $(70,6 \%)$ sedangkan yang paling rendah yaitu pengetahuan dengan kategori kurang sebanyak 4 orang $(11,8 \%)$.
Ciptaan disebarluaskan di bawah Lisensi Creative Commons Atribusi-

NonKomersial-BerbagiSerupa 4.0 Internasional.

Tabel 5 Distribusi Frekuensi Tingkat Pengetahuan tentang Tanda Bahaya Kehamilan Berdasarkan Umur

\begin{tabular}{|c|c|c|c|c|c|c|c|c|c|}
\hline \multirow{3}{*}{ No } & \multirow{3}{*}{ Umur } & \multicolumn{6}{|c|}{ Pengetahuan } & \multirow{3}{*}{$\Sigma$} & \multirow{3}{*}{$\%$} \\
\hline & & \multicolumn{2}{|c|}{ Baik } & \multicolumn{2}{|c|}{ Cukup } & \multicolumn{2}{|c|}{ Kurang } & & \\
\hline & & $\Sigma$ & $\%$ & $\Sigma$ & $\%$ & $\Sigma$ & $\%$ & & \\
\hline 1 & $<20$ tahun & 2 & 5,9 & 3 & 8,8 & 1 & 2,9 & 6 & 17,6 \\
\hline 2 & $21-25$ tahun & 10 & 29,4 & 1 & 2,9 & 1 & 2,9 & 12 & 35,3 \\
\hline 3 & 26- 30 tahun & 7 & 20,6 & 1 & 2,9 & 1 & 2,9 & 9 & 26,5 \\
\hline 4 & $31-35$ tahun & 2 & 5,9 & 0 & 0 & 0 & 0 & 2 & 5,9 \\
\hline \multirow[t]{2}{*}{5} & $>35$ tahun & 3 & 8,8 & 1 & 2,9 & 1 & 2,9 & 5 & 14,7 \\
\hline & Jumlah & 24 & 70,6 & 6 & 17,5 & 4 & 11,6 & 34 & 100 \\
\hline
\end{tabular}

Dari tabel di atas terlihat bahwa sebagian besar yaitu sebanyak 12 orang ibu pengetahuan dengan kategori baik, dan hanya 1 orang $(2,9 \%)$ yang berpengetahuan cukup. $(35,3 \%)$ yang berusia $21-25$ tahun, 10 orang $(29,4 \%)$ diantaranya memiliki

Tabel 6 Distribusi Frekuensi Tingkat Pengetahuan tentang Tanda Bahaya Kehamilan Berdasarkan Pendidikan

\begin{tabular}{|c|c|c|c|c|c|c|c|c|c|}
\hline \multirow{3}{*}{ No } & \multirow{3}{*}{ Pendidikan } & \multicolumn{6}{|c|}{ Pengetahuan } & \multirow{3}{*}{$\Sigma$} & \multirow{3}{*}{$\%$} \\
\hline & & \multicolumn{2}{|c|}{ Baik } & \multicolumn{2}{|c|}{ Cukup } & \multicolumn{2}{|c|}{ Kurang } & & \\
\hline & & $\Sigma$ & $\%$ & $\Sigma$ & $\%$ & $\Sigma$ & $\%$ & & \\
\hline 1 & Tidak tamat SD & 0 & 0 & 0 & 0 & 0 & 0 & 0 & 0 \\
\hline 2 & Tamat SD & 1 & 2,9 & 2 & 5,9 & 4 & 11,8 & 7 & 20,6 \\
\hline 3 & Tamat SMP & 6 & 17,6 & 1 & 2,9 & 1 & 2,9 & 8 & 23,5 \\
\hline 4 & Tamat SMA & 16 & 47,1 & 2 & 5,9 & 0 & 0 & 18 & 53 \\
\hline 5 & Tamat PT & 1 & 2,9 & 0 & 0 & 0 & 0 & 1 & 2,9 \\
\hline & Jumlah & 24 & 70,5 & 5 & 14,7 & 5 & 14,7 & 34 & 100 \\
\hline
\end{tabular}

(53\%) yang berpendidikan tamatan SMA, 16

Dari tabel di atas terlihat bahwa sebagian besar yaitu sebanyak 18 orang ibu orang $(47,1 \%)$ memiliki pengetahuan dengan kategori baik, dan 2 orang (5,9\%) 
JURNAL OF NURSING PRACTICE AND EDUCATION

VOL. 01 NO. 02, JUNI 2021

DOI: $10.34305 / J N P E . V 1 I 2.291$
Ciptaan disebarluaskan di bawah

Lisensi Creative Commons Atribusi-

NonKomersial-BerbagiSerupa 4.0

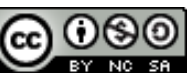

memiliki pengetahuan dengan kategori

cukup.

Tabel 7 Distribusi Frekuensi Tingkat Pengetahuan tentang Tanda Bahaya Kehamilan Berdasarkan Paritas

\begin{tabular}{|c|c|c|c|c|c|c|c|c|c|}
\hline \multirow{3}{*}{ No } & \multirow{3}{*}{ Paritas } & \multicolumn{6}{|c|}{ Pengetahuan } & \multirow{3}{*}{$\Sigma$} & \multirow{3}{*}{$\%$} \\
\hline & & \multicolumn{2}{|c|}{ Baik } & \multicolumn{2}{|c|}{ Cukup } & \multicolumn{2}{|c|}{ Kurang } & & \\
\hline & & $\Sigma$ & $\%$ & $\Sigma$ & $\%$ & $\Sigma$ & $\%$ & & \\
\hline 1 & Primipara & 7 & 20,6 & 4 & 11,8 & 2 & 5,9 & 13 & 38,2 \\
\hline 2 & Multipara & 15 & 44,1 & 2 & 5,9 & 1 & 2,9 & 18 & 53 \\
\hline 3 & Grandemulti & 2 & 5,9 & 0 & 0 & 1 & 2,9 & 3 & 8,8 \\
\hline & Jumlah & 24 & 70,6 & 6 & 17,7 & 4 & 11,7 & 34 & 100 \\
\hline
\end{tabular}

Dari tabel di atas terlihat bahwa sebagian besar yaitu sebanyak 18 orang ibu $(53 \%)$ dengan paritas multipara, 15 orang $(44,1 \%)$ memiliki pengetahuan dengan kategori baik, 2 orang $(5,9 \%)$ memiliki pengetahuan dengan kategori cukup, dan 1 orang $(2,9 \%)$ yang berpengetahuan kurang.

\section{Pembahasan}

Berdasarkan hasil penelitian didapatkan bahwa sebagian besar responden berusia 21 - 25 tahun yaitu sebanyak 12 orang ibu $(35,3 \%), 10$ orang $(29,4 \%)$ diantaranya memiliki pengetahuan dengan kategori baik, 1 orang (2,9\%) berpengetahuan cukup, dan 1 orang $(2,9 \%)$ berpengetahuan kurang.

Menurut Prawirohardjo (2011: 22) diketahui sejak lama bahwa umur sangat berpengaruh terhadap proses reproduksi. Umur yang optimal untuk kehamilan adalah antara 20 - 30 tahun, sedangkan yang dianggap berbahaya adalah kehamilan 35 tahun keatas dan 16 tahun kebawah yang disebut sebagai kehamilan remaja.

Berdasarkan hasil penelitian yang didapatkan bahwa sebagian besar yaitu sebanyak 18 orang ibu $(52,9 \%)$ yang berpendidikan tamatan SMA, 16 orang $(47,1 \%)$ memiliki pengetahuan dengan kategori baik, dan 2 orang $(5,9 \%)$ memiliki pengetahuan dengan kategori cukup.

Tingkat pendidikan rendah mengakibatkan kurangnya pengetahuan ibu dalam menghadapi masalah, pengetahuan dapat diperoleh baik formal maupun informal. Ibu yang mempunyai pendidikan tinggi umumnya terbuka menerima perubahan atau hal-hal baru guna 
JURNAL OF NURSING PRACTICE AND EDUCATION VOL. 01 NO. 02, JUNI 2021

DOI: $10.34305 / J N P E . V 1 I 2.291$

pemeliharaan kesehatan, (Ihsan, 2015, hal. $1-2)$.

Berdasarkan hasil penelitian didapat bahwa sebagian besar yaitu sebanyak 18 orang ibu (53\%) dengan paritas multipara, 15 orang $(44,1 \%)$ memiliki pengetahuan dengan kategori baik, 2 orang $(5,89 \%)$ memiliki pengetahuan dengan kategori cukup, dan 1 orang $(2,9 \%)$ yang berpengetahuan kurang.

Hal ini juga diperkuat oleh pendapat Notoatmodjo, (2012) bahwa pengalaman merupakan guru yang terbaik, yang diartikan bahwa pengalaman merupakan sumber pengetahuan, atau pengalaman itu merupakan suatu cara untuk memperoleh suatu kebenaran pengetahuan. Oleh sebab itu pengalaman pribadi pun dapat dijadikan sebagai upaya untuk memperoleh pengetahuan. Hal ini dilakukan dengan cara mengulang kembali pengetahuan yang diperoleh dalam memecahkan persoalan yang dihadapi pada masa lalu.

Berdasarkan hasil penelitian bahwa sebagian besar responden memiliki tingkat pengetahuan baik sebanyak 24 orang $(70,6 \%)$. Dapat digambarkan bahwa pengetahuan berhubungan erat dengan tingkat pendidikan yang dimiliki seseorang. Semakin tinggi tingkat pendidikan yang dimiliki seseorang maka semakin tinggi pula
Ciptaan disebarluaskan di bawah Lisensi Creative Commons AtribusiNonKomersial-BerbagiSerupa 4.0

Internasional.

pengetahuan orang tersebut. Sedangkan menurut Santrock (2014), pengetahuan adalah hasil dari proses pembelajaran dengan melibatkan indera penglihatan, pendengaran, penciuman, dan pengecap. Pengetahuan akan memberikan penguatan terhadap individu dalam setiap mengambil keputusan dan dalam berperilaku.

\section{Kesimpulan}

Setelah dilakukan penelitian tentang hubungan karakteristik ibu hamil dengan tingkat pengetahuan ibu hamil tentang tanda bahaya kehamilan di Desa Sengon Kecamatan Tanjung Kabupaten Brebes, maka dapat diambil kesimpulan sebagai berikut :Gambaran tingkat pengetahuan ibu hamil tentang tanda bahaya kehamilan berdasarkan karakteristik ibu hamil di Desa Sengon Kecamatan Tanjung Kabupaten Brebes berdasarkan umur yaitu berumur antara 21 - 25 tahun yaitu 10 orang $(29,4 \%)$ diantaranya memiliki pengetahuan dengan kategori baik. Gambaran tingkat pengetahuan ibu hamil tentang tanda bahaya kehamilan berdasarkan karakteristik ibu hamil di Desa Sengon Kecamatan Tanjung Kabupaten Brebes berdasarkan pendidikan sebagian besar yaitu 18 orang ibu $(52,9 \%)$ berpendidikan tamatan SMA 16 orang $(47,1 \%)$ diantaranya memiliki pengetahuan 
JURNAL OF NURSING PRACTICE AND EDUCATION VOL. 01 NO. 02, JUNI 2021

DOI: $10.34305 / J N P E . V 1 I 2.291$

dengan kategori baik. Gambaran tingkat pengetahuan ibu hamil tentang tanda bahaya kehamilan berdasarkan karakteristik ibu hamil di Desa Sengon Kecamatan Tanjung Kabupaten Brebes berdasarkan paritas bahwa sebagian besar yaitu 18 orang ibu (53\%) dengan paritas multipara 15 orang $(44,1 \%)$ diantaranya memiliki pengetahuan dengan kategori baik.

\section{Saran}

Pentingnya pemeriksaan kehamilan secara teratur bagi setiap ibu hamil agar tanda bahaya kehamilan dapat terdeteksi sedini mungkin sehingga penyulit dan komplikasi yang mungkin terjadi pada saat kehamilan dan persalinan dapat diketahui secara dini dan dapat dilakukan penanganan yang tepat.

\section{Daftar Pustaka}

Depkes R I. (2014). Pemantauan Wilayah Setempat Kesehatan Ibu dan Anak (PWS - KIA). Departemen Kesehatan RI.

Ihsan, F. (2015). HA Filsafat Ilmu. Rineka Cipta.

Notoatmodjo, S. (2010). Metodologi penelitian kesehatan. Jakarta: Rineka Cipta, 50.

Notoatmodjo, S. (2012). Promosi kesehatan dan perilaku kesehatan. Rineka cipta.
Ciptaan disebarluaskan di bawah Lisensi Creative Commons AtribusiNonKomersial-BerbagiSerupa 4.0 Internasional.

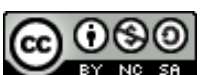

Notoatmodjo, S. (2017). Konsep Pengetahuan, Pendidikan dan Perilaku Kesehatan. Rineka Cipta.

Prawirohardjo, S. (2011). Ilmu kebidanan (Edisi ke-4). Yayasan Bina Pustaka.

Saifuddin, A. B. (2018). Buku panduan praktis pelayanan kesehatan maternal dan neonatal. Yayasan Bina Pustaka Sarwono Prawiroharjo.

Santrock, J. (2014). Psikologi Pendidikan (Tri Wibowo). Salemba Humanika.

Statistik, B. P. (2015). Survei Demografi dan Kesehatan Indonesia (SDKI) 2015. Badan Pusat Statistik.

Varney, H., Kriebs, J. M., \& Gegor, C. L. (2007). Buku ajar asuhan kebidanan. ECG. 